\title{
Impact of intercropping on yield, fruit quality and economics of young Kinnow mandarin plants
}

M.S. Gill

Punjab Agricultural University, Department of Fruit Science, Ludhiana (Punjab), India

\section{Savreet Khehra}

Punjab Agricultural University, Farm Advisory Service Center, Tarn Taran-143401 (Punjab), India

Navjot Gupta

Punjab Agricultural University, Regional Research Station, Bathinda-151001(Punjab), India

*Corresponding author. E-mail: mandeepgill21@pau.edu

\begin{abstract}
Intercropping practices in orchard not only generate an extra income but the practice also helps to check the soil erosion through ground coverage and improves the physicochemical properties of the soil.. The effect of intercrops on vegetative performance and quality of 5 years old Kinnow mandarins raised on Rough Lemon rootstocks at $6 \times 6 \mathrm{~m}$ spacing was studied at RRS, Bathinda during the year 2011-12 and 2012-13. An intercropping experiment comprising of seven treatments such as $T_{1}$ : guara (Summer) + wheat (winter), $\mathrm{T}_{2}$ : guara (summer) + barley (winter), $\mathrm{T}_{3}$ : guara (summer) + fenugreek (winter), $\mathrm{T}_{4}$ : moong (summer) + wheat (winter), $\mathrm{T}_{5}$ : moong (summer) + barley (winter), $\mathrm{T}_{6}$ : moong (summer) + fenugreek (winter) and $\mathrm{T}_{7}$ : control (fallow: no intercrop) was laid out in Randomized Block Design with four replications to assess the effect of various intercrops on the performance of Kinnow in arid irrigated region of Bathinda, Punjab. The results of the study revealed that guar + wheat intercropping system exhibited better performance which has been reflected in the form of plant height $(3.31 \mathrm{~cm})$, gross income (Rs. 41180/-), fruit number (175) and Total Soluble Solids(TSS) per cent (10.8) of Kinnow fruit. The work concludes that intercropping in Kinnow mandarin helps to improve yield, fruit quality and economic aspect.
\end{abstract}

Keywords: Fruit quality, Income, Intercrop, Plant growth, Yield

\section{INTRODUCTION}

Intercropping is one of the techniques of land utilization for optimum production (Bhatnagar et al., 2007). The leguminous intercrops were the most effective crop because of their desirable impact on improvement of nutrient status of soil and fruit plant of orchard. Experimental evidences have also proved that yield stability is greater with intercropping than sole cropping. Intercropping can provide substantial yield advantages compared with sole cropping. However, the success of intercropping system depends mainly on selection of suitable intercrop as the pre harvest management practices influence the Kinnow growth (Din et al., 2012).

Intercropping in orchards is a common practice in many countries. It has been observed that intercropping of mustard with bananas and cucumber with citrus (mandarin) orchards improved the yields yield of banana and citrus in India (Ouma and Jeruto, 2010). Intercropping of legumes in citrus orchards is beneficial for the citrus produc-

\section{Article Info}

DOI:10.31018/jans.v10i3.1814

Received: July 3, 2018

Revised: July 25, 2019

Accepted: August 5, 2018

\section{How to Cite}

Gill, M.S. et al. (2018).

Impact of intercropping on yield, fruit quality and economics of young Kinnow mandarin plants. Journal of Applied and Natural Science, 10(3): 954 - 957 
Gill, M.S. et al. / J. Appl. \& Nat. Sci. 10 (3): 954 - 957 (2018)

quires irrigation weekly while citrus requires less water. The excessive use of water deoxygenates the root system of citrus plants that affects yield and growth. Similarly, at harvesting time of wheat, irrigation is stopped but orchards require irrigation at that time which adversely affects yield and growth of citrus (Srivastava et al., 2007 and Sarwar et al., 2012). Thus, there is need to identify suitable intercrop which remains compatible throughout the growth of main crop. The present study aims to assess the impact of intercropping on Kinnow yield, fruit quality and economic aspect.

\section{MATERIALS AND METHODS}

The experiment was conducted on five years old Kinnow mandarins plants raised on rough lemon rootstocks at $6 \times 6 \mathrm{~m}$ spacing at RRS, Bathinda during the year 2011-12 and 2012-13 to find out the feasibility of suitable intercrop in young Kinnow mandarin in arid irrigated region of Bathinda and to study effect of intercrops on main crop. There were seven treatments with six crop rotation practices for intercropping in non bearing Kinnow orchard having four replications. The cultural practices were given as per schedule recommended by PAU, Ludhiana.

The tree vigor of Kinnow mandarin was measured on the basis of increment in height, spread and scion girth at the start (March) and after termination of the experiment (January). The height and tree spread of each selected tree was measured with the help of calibrated bamboo pole. To get a tree spread (canopy diameter) two observations, one each on east-west and north-south sides of selected tress were recorded. The circumferential measurement was taken $5 \mathrm{~cm}$ above the bud union in the budded plants for trunk girth.. The percentage of the juice was calculated on fresh weight basis. The chemical characters like TSS and acidity were measured as per standard procedures of A.O.A.C (1990). The statistical analysis was done using Randomized Block Design (Gomez and Gomez, 1984).

\section{RESULTS AND DISCUSSION}

Among growth parameters, the maximum increase in plant height $(3.05 \mathrm{~cm}$ and $3.31 \mathrm{~cm})$ during both the years was found in crop rotation guar + wheat however, minimum plant height $(2.08 \mathrm{~cm}$ and $2.40 \mathrm{~cm}$ ) was found in crop rotation guar + fenugreek during both the years as shown in table

Table 1. Treatment details.

\begin{tabular}{lll}
\hline $\mathrm{T}_{1}$ & $:$ & Guara (Summer) + Wheat (winter) \\
$\mathrm{T}_{2}$ & $:$ & Guara (summer) + Barley (winter) \\
$\mathrm{T}_{3}$ & $:$ & Guara (summer) + Fenugreek (winter) \\
$\mathrm{T}_{4}$ & $:$ & Moong (summer) + Wheat (winter) \\
$\mathrm{T}_{5}$ & $:$ & Moong (summer) + Barley (winter) \\
$\mathrm{T}_{6}$ & $:$ & Moong (summer) + Fenugreek (winter) \\
$\mathrm{T}_{7}$ & $:$ & Control (Fallow : No intercrop) \\
\hline \hline
\end{tabular}

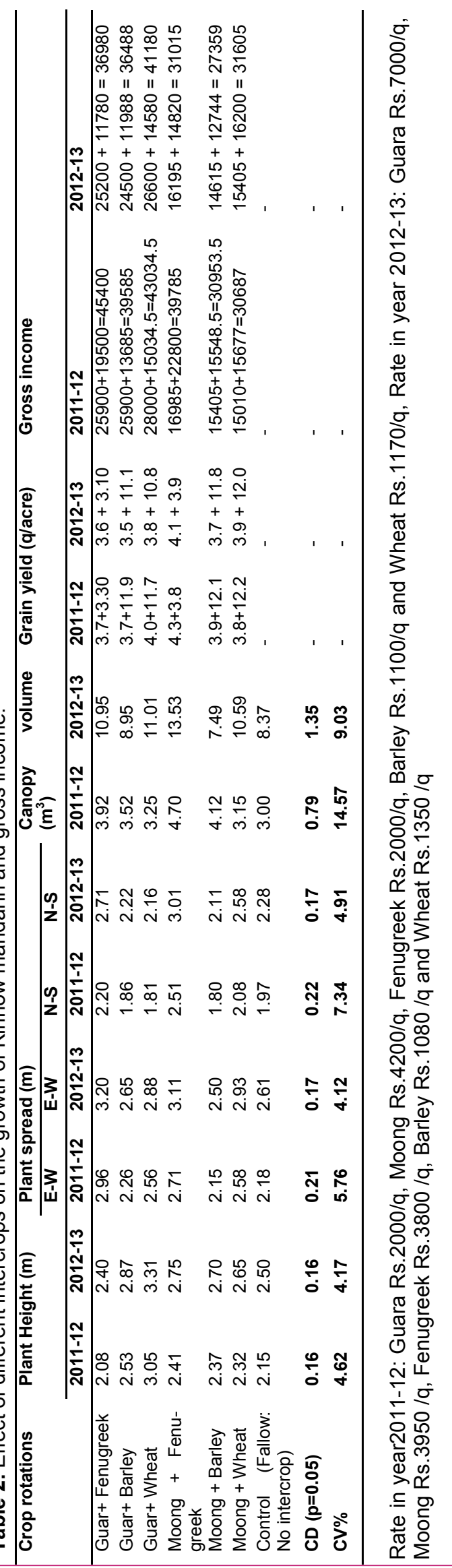




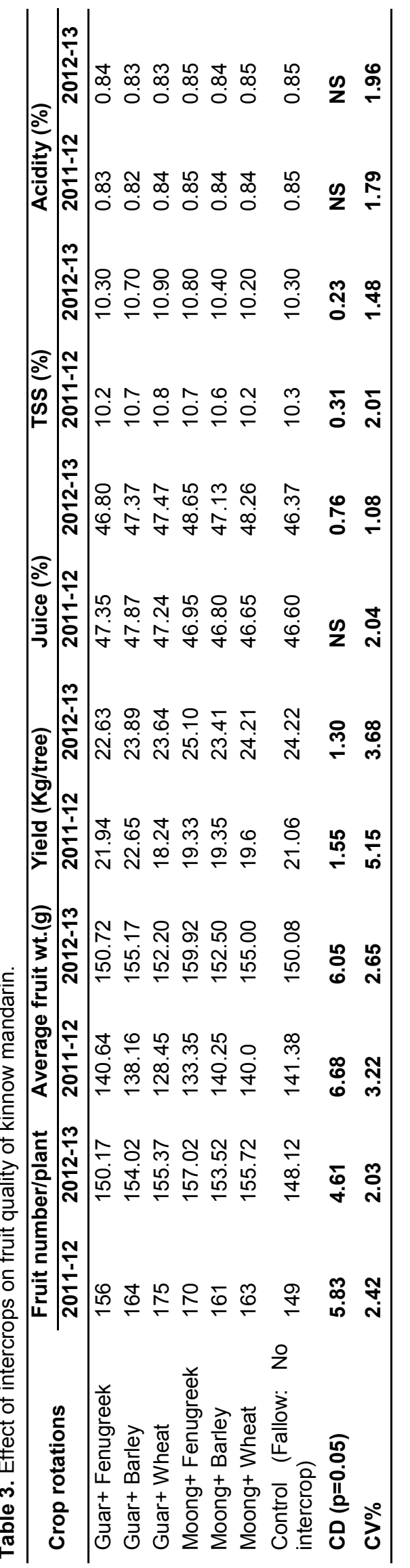

2. Among the different crop rotations, the moong + fenugreek crop rotation showed positive response on plant spread (N-S) having values $2.51 \mathrm{~cm}$ and $3.01 \mathrm{~cm}$ and canopy volume $\left(7.70 \mathrm{~m}^{3}\right.$ and 13.53 $\mathrm{m}^{3}$ ), respectively in table 2 . Singh et al.(2016) reported that better growth of guava trees intercropped with tuber crops resulted in better plant height and spread which may be due to better orchard floor management. The minimum plant spread E-W $(2.15 \mathrm{~cm}$ and $2.50 \mathrm{~cm})$ and N-S $(1.80$ $\mathrm{cm}$ and $2.11 \mathrm{~cm}$ ) during 2011-12 and 2012-13 as depicted in table 2 was found in crop rotation moong + barley. The lowest canopy volume was calculated under control. However, maximum gross income (Rs. 41180/-) was earned during 2012-13 in crop rotation guar + wheat followed by guar + fenugreek (36980/-) which has been depicted in table 2. However, minimum gross income was earned from crop rotation moong + barley.

Adoption of intercropping systems in orchard helps in efficient utilization of natural resources as well as it improves the input use efficiency in the system (Panda et al., 2003). This might be the reason for increase in growth parameters of main crop. Similar findings on increase in tree height, girth and canopy area due to intercropping were reported by Mishra and Swain (2001), Vishal Nath et al. (2003) and Swain and Patro (2007) in mango. Intercropping with legume crops in orchard was more effective which might have helpful in substantial increase in nitrogen content of the soil as well as other physico-chemical properties of soil resulting in better vegetative growth in main crop. This corroborates with the findings of Vishal Nath et al. (2003) and Swain and Patro (2007) in mango. The higher yield advantages particularly average fruit weight $(\mathrm{g})$ and fruit yield( $\mathrm{kg} /$ tree $)$ under intercropping systems were mainly attributed to efficient utilization of natural resources like solar radiation, soil moisture and nutrients because of complementary interaction between the component crops.

The maximum number of fruits per plant (175) (Table 3 ) was observed under crop rotation guar + wheat whereas minimum number of fruits per plant (148.12) were counted under control. The increase in fruit number as observed under different systems may be explained from the fact that some leguminous intercrops like guar have the capacity of fixing the atmospheric nitrogen to the soil and there by main crop would have got additional nitrogen, which agrees well to the findings of Ghosh (2001) in guava in terms of number of fruits per plant. Moreover, intercrops help the main crop through indirect way like creating a micro climate that may have resulted in improvement of fruit number and fruit yield. Sahoo (2016) reported that the average mango yield was higher in the intercropping systems than the sole mango crop. Besides, floor management for the intercrops like 
land preparation for sowing, weeding, etc. seemed to be beneficial for higher production of fruits. The intercropping that helped to improve the fruit production of the mango crop was also reported by Ghosh (2001) in guava and Rath and Swain (2006) in mango. The guar+wheat intercropping system resulted in maximum TSS per cent (10.8 and 10.9) in both the years as per Table 3.Similar results in terms of fruit quality were reported by Swain (2016) in mango.

\section{Conclusion}

The study showed that guar + wheat intercropping system resulted in enhanced performance which has been depicted in the form of plant height (3.31 $\mathrm{cm}$ ), gross income (Rs. 41180/-), fruit number (175) and total soluble solids per cent (10.8) of Kinnow fruit. The work concludes that intercropping in Kinnow mandarin helps to improve yield, fruit quality and economic aspect. Lack of knowledge about intercropping in citrus may result in low yield and short life span of main crop. Thus, the more suitable intercrops should be identified keeping in view the supplementary and complimentary relationships among the citrus and the intercrops such as legumes.

\section{REFERENCES}

1. AOAC (1990). Official methods of Analysis of Analytical Chemists, $15^{\text {th }}$ Edition (Ed. W. Horowitz). Association of the Official Analytical Chemists, Washington, DC, USA.

2. Ahmed, S., M.A. Khan and M. Qasam (2013). Effect of intercropping of maize in citrus orchards on Citrus Leaf Miner infestation and population of its natural enemies. Pak. J. Agric Sci., 50:91-93.

3. Aziz, R.A.A., S.E. Salem and L. Al-Bitar (2008). Effect of intercropping cover crops on citrus orchards growth and fruiting under Toshka conditions. J. Agric. Vet. Sci., 1:101-110.

4. Bhatnagar, P., Kaul, M. K. and Singh, J. (2007). Effect of intercropping in Kinnow based production system. Indian J. Arid Hort., 2:15-17.

5. Din, A., Asghar, M., Parveen, S. and Ali, M.A. (2012). Evaluation of Kinnow mandarin as influenced by preharvest management practices. J. Agric. Res., 50(3): 381-391.

6. Ghosh, S. N. (2001). Intercropping in guava orchard in watershed area. Hort. J., 14: 36-40.

7. Gomez, K.A. and Gomez, A.A. (1984). Statistical procedures for agricultural research. John Wiley and Sons, Ink., New York.

8. Hnamte, V., Gopichand, B. and Lalnunmawia, F. (2013). Study on economic feasibility of intercropping of lemon (Citrus limon Burm) with vegetables in the hilly terrain of Mizoram. Sci. Vision. 13:40-44.

9. Ijaz, A., Adil, S.A., Hassan, S., Bakhsh, K., Bashir, M.K. and Abbas, Q. (2014). Agro-economic dimensions of intercropping in citrus farms: The case of district Toba Tek Singh, Pakistan, Pak. J. Agri. Sci., 51(3), 763-767

10.Linares, J., Scholberg, J., Boote, K., Chase, C.A., Ferguson, J.J. and McSorley, R. (2008). Use of the cover crop weed index to evaluate weed suppression by cover crops in organic citrus orchards. Hort Sci., 43:27-34.

11.Mishra, P. J. and Swain, S. C. (2001). A note on evaluation of different agri-horti systems in watersheds for Eastern Ghat High land zone of Orissa. Orissa J. Hort., 29:112-14.

12. Ouma, G. and Jeruto, P. (2010). Sustainable horticultural crop production through intercropping: The case of fruits and vegetable crops: A review. Agric. Biol. J. N. Am., 1:1098-1105.

13.Panda, M. M., Nandi, A., Bhoi, N., Senapati, N., Barik, K. C., Sahu, S. K., and Sahoo, B. C. (2003). Studies on identification of suitable intercrops for degraded land management in the North Central Plateau Agro climatic Zone of Orissa. J. Res. Orissa, Univ. Agric. Tech., 21: 62-66.

14.Rath, S. and Swain, S. C. (2006). Performance of intercrops in bearing mango orchards in Eastern Ghat High land zones of Orissa. Indian J. Dryland Agric. Res. Dev., 21: 12 - 15.

15.Sahoo, U. K. (2016). Effect of Intercropping on Soil Health and Yield Potential of Mango in Paradise Valley, East Kawlchaw, Saiha District of Mizoram, NE India. Intl. J. Ecol. Envir.Sc.,42(3):227-237

16.Sarwar, G., Anwar, A. and Sial, M.H. (2012). Quality of inputs and technical efficiency nexus of citrus farmers: a case study of Sargodha district, Punjab (Pakistan). Int. J. Acad. Res. Bus. Soc. Sci., 2:315323.

17.Singh, S.K., Sharma, M. and Singh, P.K. (2016). Intercropping- An approach to reduce fruit drop and improve fruit quality in guava. J. Chem. Pharm. Sc., 9 (4):3182-3187.

18.Srivastava, A.K., A.D. Huchche, L. Ram and S. Singh. (2007). Yield prediction in intercropped versus mono-cropped citrus orchards. Scientia Hort., 114:67 -70 .

19.Swain, S.C. (2016). Influence of Intercropping Systems on Soil Health, Productivity and Quality of Guava (Psidium guajava L.) in Eastern India. J Plant Nutri, 39(14): 2037-2046.

20.Swain, S. C. and Patro, L. (2007). Horticulture based cropping system -A strategy for sustainable development in rainfed upland. In: Environmental Hazards (Eds: L. Patro and S. N. Tripathy), Sonali Publication, New Delhi, pp: 44-69.

21.Vishal Nath, Das, B., Rai, M., Dey, P., Kumar, S. and Kumar, M. (2003). Mango based cropping system for uplands of sub-humid plateau region of Eastern India. Prog. Hort., 35: $142-45$. 